\title{
DAMPAK VARIABEL MAKROEKONOMI DAN INDEKS SAHAM GLOBAL TERHADAP INDEKS HARGA LQ45 DI BURSA EFEK INDONESIA
}

\author{
Nuryasman MN dan Verencia Permatasari \\ Fakultas Ekonomi Universitas Tarumanaara \\ Email:nuryasman@fe.untar.ac.iddanverencia_permatasari@yahoo.com
}

\begin{abstract}
The objective of this research was to examine the macroeconomics variable and global stock price index that influencing LQ45 stock price. There were three fundamental macroeconomics variables in this study such as Exchange rate of Rupiah, Interest Rate (SBI), and gold prices which used with global stock price index (Dow Jones Industrial Average) to examine their influence to LQ45 stock price. The sampling data used are 69 months from 2009 January until 2014 September. The selection ofthe sample usedisa non-probability sampling method, using purposive sampling technique. The method usedis multiple regression analysis and Error Correction Model (ECM)using softwareEviews6.0witha significance level of 5\%. The result of t-test show that gold prices have not influence LQ45 stock price. While the Exchange rate of Rupiah, Interest Rate (SBI), and Dow Jones Industrial Average have influence LQ45 stock price.The result of F- test (jointly test) showthat there are significantjointlybetween Exchange rate of Rupiah, Interest Rate (SBI), gold price, and Dow Jones Industrial Averageon LQ45 stock price. The result of ECM Models show that between Exchange rate of Rupiah, Interest Rate (SBI), gold price, and Dow Jones Industrial Averageon LQ45 stock price, there was notable toachieve abalance inthe long run.
\end{abstract}

Keywords: Macroeconomics, global stock index, LQ45 index, OLS, ECM

\begin{abstract}
Abstrak: Penelitian ini bertujuan untuk menguji pengaruhvariabel makroekonomi (kurs Rupiah/USD , suku bunga SBI, dan harga emas dunia) dan indeks saham global (Indeks Dow Jones) terhadap indeks harga LQ45. Periode penelitian ini dari bulan Januari 2009 sampai September 2014. Metode pemilihan sampel yang digunakan dalam penelitian ini adalah non-probability sampling, dengan menggunakan teknik purposive sampling. Teknik analisis yang digunakan adalah analisis regresi berganda dan Error Correction Model(ECM) dengan menggunakan software Eviews 6.0 dengan tingkat signifikansi 5\%. Hasil dari uji-t menunjukkan bahwa harga emas tidak memiliki pengaruh terhadapindeks harga LQ45. Sementara, nilai tukar Rupiah, suku bunga (SBI), dan Indeks Dow Jones memiliki pengaruh yang signifikan terhadap indeks harga LQ45 . Hasil dari uji-F menunjukkan bahwa kurs RP/USD, suku bunga (SBI), harga emas dunia, dan Indeks Dow Jones secara bersama-samamemiliki pengaruh yang signifikan terhadapindeks harga LQ45.Hasil dari analisis ECM menunjukkan bahwa indeks harga LQ45tidak mencapai keseimbangandalam jangka panjang akibat perubahannilai tukar RP/USD, suku bunga (SBI), harga emas dunia, dan Indeks Dow Jones.
\end{abstract}

Kata kunci: Makroekonomi, indeks saham global, indeks LQ45, OLS, ECM 


\section{PENDAHULUAN}

Perkembangan sektor ekonomi global saat ini didominasi oleh peranan pasar modal. Adanya globalisasi telah memungkinkan hubungan saling terkait dan saling mempengaruhi dari hampir seluruh pasar modal di dunia, sehingga para investor perlu memperhatikan beberapa faktor penting dalam mempertimbangkan keputusan investasi dalam pasar modal.

Pasar modal (capital market) merupakan tempat diperjualbelikannya instrumen keuangan jangka panjang, seperti utang, ekuitas (saham), instumen derivatif (Darmadji dan Fakhrudin ,2006). Pasar modal juga merupakan representasi untuk menilai kondisi perusahaan-perusahaan di suatu negara karena hampir semua industri di suatu negara terwakili oleh pasar modal. Oleh karena itu, pasar modal merupakan salah satu alat penggerak perekonomian suatu negara yaitu dengan adanya sarana bagi kegiatan berinvestasi.

Menurut Samsul (2006), investasi merupakan kegiatan menanamkan modal baik langsung maupun tidak langsung dengan harapan pada waktunya nanti pemilik modal mendapatkan sejumlah keuntungan dari hasil penanaman modal tersebut. Bagi para investor, melalui pasar modal dapat memilih obyek investasi dengan beragam tingkat pengembalian dan tingkat risiko yang dihadapi, sedangkan bagi para penerbit (issuers atau emiten) melalui pasar modal dapat mengumpulkan dana jangka panjang untuk menunjang kelangsungan usaha. Kondisi pasar dalam perdagangan saham biasanya dilihat dari frekuensi perdagangan. Perdagangan saham dalam keadaan ramai (frekuensi perdagangan tinggi), dikatakan pasar dalam keadaan bullish, sebaliknya, apabila frekuensi perdagangan rendah, kondisi ini disebut pasar dalam keadaan bearish (Widoatmodjo,2000).

Investor yang berminat untuk berinvestasi di pasar modal di Indonesia dapat berinvestasi di Bursa Efek Indonesia (BEI).Setiap investor memerlukan informasi yang relevan untuk membuat keputusan investasi termasuk informasi mengenai faktor ekonomi makro yang dapat mempengaruhi kinerja saham.

Khan (2012), menyatakan bahwa harga saham bertindak sebagai indikator ekonomi yang penting dalam kegiatan ekonomi. Salah satu indeks yang sering diperhatikan investor ketika berinvestasi di Bursa Efek Indonesia adalah harga Saham Indeks LQ45.

Indeks LQ 45 terdiri dari 45 perusahaan yang memenuhi kriteria tertentu, seperti : termasuk dalam top 60 perusahaan dengan kapitalisasi pasar tertinggi dalam 12 bulan terakhir, telah dicatatkan di Bursa Efek Indonesia selama 3 bulan, memiliki kondisi keuangan yang baik, prospek pertumbuhan dan nilai transaksi yang tinggi dan frekuensi.

Menurut Blanchard (2006), banyak faktor yang dapat mempengaruhi Indeks harga saham, antara lain tingkat suku bunga bank sentral, keadaan ekonomi global, tingkat harga energi dunia, kestabilan politik suatu negara, dan lain-lain. Selain faktor tersebut, perilaku investor sendiri juga akan memberi pengaruh terhadap pergerakan indeks saham.

Kurs merupakan salah satu harga terpenting dalam perekonomian terbuka mengingat pengaruhnya yang demikian besar bagi transaksi berjalan maupun variabel-variabel makro yang lainnya. Hasil penelitian yang dilakukan Kewal (2012) menemukan adanya pengaruh negatif nilai tukar terhadap harga saham. Rendahnya nilai tukar akan mendorong investor menanamkan modal di bursa saham sehingga harga saham akan naik. Hal ini mengindikasikan bahwa hubungan kurs rupiah dan harga saham berlawanan arah, artinya semakin kuat kurs rupiah terhadap USD (rupiah terapresiasi) maka akan meningkatkan 
harga saham. Sebaliknya, jika semakin lemah kurs rupiah terhadap USD (rupiah terdepresiasi) maka akan menurunkan harga saham.

Di Indonesia kebijakan tingkat suku bunga dikendalikan secara langsung oleh Bank Indonesia melalui BI rate. BI rate merupakan respon bank sentral terhadap tekanan inflasi ke depan agar tetap berada pada sasaran yang telah ditetapkan. Perubahan BI rate dapat memicu pergerakan di pasar saham Indonesia. Penurunan BI rate secara otomatis akan memicu penurunan tingkat suku bunga kredit maupun deposito. Bagi para investor, dengan penurunan tingkat suku bunga deposito, akan mengurangi tingkat keuntungan yang diperoleh bila dana yang mereka miliki diinvestasikan dalam bentuk deposito.

Selain suku bunga SBI, emas merupakan salah satu komoditi penting yang dapat mempengaruhi pergerakan bursa saham. Hal ini didasari bahwa emas merupakan salah satu alternatif investasi yang cenderung aman dan bebas risiko (Sunariyah, 2006). Emas tersedia dalam berbagai macam bentuk, mulai dari batangan atau lantakan, koin emas dan emas perhiasan. Emas yang berbentuk seperti batangan pipih atau batubata, dimana kadar emasnya adalah 22 atau 24 karat, atau apabila dalam persentase adalah 95\% dan 99\% disebut emas batangan. Jenis emas ini adalah yang terbaik untuk investasi karena dimana pun dan kapan pun investor ingin menjualnya, nilainya akan selalu sama. Nilai ini mengikuti standar internasional yang berlaku nilainya pada hari penjualan lagi. Oleh sebab itu, kenaikan harga emas akan mendorong penurunan indeks harga saham karena investor yang semula berinvestasi di pasar modal akan mengalihkan dananya untuk berinvestasi di emas yang relatif lebih aman daripada berinvestasi di bursa saham.

Indeks yang dianggap dapat mewakili pasar saham Amerika Serikat dan sekaligus pasar saham global adalah Indeks Dow Jones. Indeks Dow Jones merupakan indeks pasar saham tertua di Amerika Serikat dan merupakan representasi dari kinerja industri terpenting di Amerika Serikat (www.nyse.com). Perusahaan yang tercatat di Indeks Dow Jones pada umumnya merupakan perusahaan multinasional. Kegiatan operasi mereka tersebar di seluruh dunia. Indeks Dow Jones yang bergerak naik, menandakan kinerja perekonomian Amerika Serikat secara umum berada pada posisi yang baik. Dengan kondisi perekonomian yang baik, akan menggerakkan perekonomian Indonesia melalui kegiatan ekspor maupun aliran modal masuk baik investasi langsung maupun melalui pasar modal (Sunariyah,2006). Aliran modal yang masuk melalui pasar modal tentu akan memiliki pengaruh terhadap perubahan LQ45.

\section{KAJIAN TEORI}

Indeks LQ45. Menurut Jones (2008) LQ45 Index consist of 45 based on: trading liquidity and market capitalization, this index is reviewed every 6 months. (LQ45 Indexterdiri dari 45 berdasarkan likuiditas perdagangan dan kapitalisasi pasar, indeks ini disesuaikan setiap 6 bulan).

Darmadji dan Fakhrudin (2006) menguraikan, Indeks LQ45 merupakan indeks yang terdiri atas 45 saham pilihan dengan mengacu pada dua variabel, yaitu likuiditas perdagangan dan kapitalisasi pasar. Setiap enam bulan, terdapat saham-saham baru yang masuk ke dalam LQ45.

Dari definisi - definisi diatas, maka dapat disimpulkan bahwa LQ45 adalah indeks harga saham 45 perusahaan yang memiliki likuiditas tinggi di Indonesia dan memiliki kapitalisasi pasar terbesar yang terdaftar di dalam BEI. 
Nilai Tukar RP/USD. Keown, et. al. (2002), Exchange rate is the price of foreign currency stated in terms of the domestic or home currency. Artinya bahwa nilai tukar adalah harga atau nilai dari mata uang asing yang dinyatakan dalam mata uang domestik atau mata uang negara asal.

Ross, et al. (2003), Exchange rate is the price of one country's currency expressed in terms of another country's currency. Artinya bahwa nilai tukar merupakan harga mata uang suatu negara yang dinyatakan dalam mata uang negara lain.

Siamat (2005), dalam transaksi valas internasional, Dollar Amerika Serikat sering dijadikan sebagai mata uang referensi dalam penentuan kurs mata uang asing lain.

Dari definisi - definisi diatas dapat disimpulkan bahwa kurs IDR/USD adalah nilai mata uang Rupiah yang dibutuhkan untuk memperoleh satu unit mata uang USD sesuai dengan nilai yang dinyatakan pada saat transaksi tersebut.

Suku Bunga SBI. Gitman (2013), interest rate usually applied to debt instruments such as bank loans or bonds; the compensation paid by the borrower of funds to the lender; from the borrower's point of view, the cost of borrowing funds. Artinya bahwa suku bungabiasanyaditerapkan untuk instrumen hutangseperti pinjamanbank atauobligasi; kompensasi yang dibayarkanoleh peminjamdanakepada kreditur; dari sudutpandang peminjam, biaya dari danapinjaman.

Siamat (2005), Sertifikat Bank Indonesia atau SBI pada prinsipnya adalah surat berharga atas unjuk dalam rupiah yang diterbitkan oleh Bank Indonesia sebagai pengakuan utang berjangka waktu pendek dan diperjual belikan dengan diskonto. Tingkat suku bunga SBI merupakan variabel penting yang digunakan sebagai penentu suku bunga yang lain (Adiningsih, 2008).

Dari definisi - definisi diatas maka dapat disimpulkan bahwa suku bunga yang harus dibayarkan oleh peminjam dana kepada penyedia dana sebagai imbalan atas pinjaman yang diberikan dan suku bunga SBI berfungsi sebagai dasar penentu dalam penetapan tingkat suku bunga lainnya.

Harga Emas Dunia. Witjaksono (2010) dalam Silim (2013), harga emas dunia adalah harga spot yang terbentuk dari akumulasi penawaran dan permintaan di pasar emas London. Hal ini didasari bahwa emas merupakan alternatif investasi yang cenderung aman dan bebas risiko (Sunariyah,2006). Selain itu, harga emas juga selalu stabil setiap waktu dan bersifat likuid (mudah diuangkan). Keunikan lain dari emas adalah emas mampu menaklukan inflasi karena nilainya stabil. Bila inflasi tinggi, harga emas akan naik lebih tinggi daripada inflasi. Semakin tinggi inflasi semakin tinggi kenaikkan harga emas. Sehingga emas banyak dijadikan alat save heaven oleh para investor untuk meyelamatkan kekayaannya. Ismanthono (2003), harga emas merupakan harga pada waktu suatu efek untuk pertama kalinya dikeluarkan di pasar. Biasanya disebut harga perdana yang biasanyadi atas dari harga nominal.

Dari definisi - definisi diatas dapat disimpulkan bahwa harga emas dunia adalah harga logam mulia emas yang ditetapkan di pasar emas dunia dalam dollar AS, serta bersifat stabil, mudah diuangkan, bebas risiko.

Indeks Dow Jones. Menurut Jones (2008) dan Riantani (2013), Dow Jones Industrial Average (DJIA) is a price-weighted series of 30 leading industrial stocks, used as a measure of stock market activity. (Dow Jones Industrial Average (DJIA) adalah 
serangkaian harga tertimbang dari 30 saham industri terkemuka,digunakan sebagai ukuran aktivitas pasar saham). Amin (2012) mendefinisikan Indeks Dow Jones adalah indeks utama pada bursa New York dan perhitungannya menggunakan sampel seluruh saham yang terdaftar di bursa saham NYSE.

Dari definisi - definisi diatas dapat disimpulkan bahwa Indeks Dow Jones adalah suatu dasar indeks tertua di Amerika yang digunakan sebagai tolok ukur kinerja bursa saham yang paling banyak dipakai di dunia.

Valuation Stock. Saat melakukan pembelian atau penjualan saham, investor akan melakukan penilaian agar dapat menghasilkan return yang sesuai dengan yang diharapkan oleh investor. Penilaian tersebut adalah penilaian saham, yang dimana menggambarkan nilai intrinsik/wajar suatu saham yang akan dibandingkan dengan harga pasar saham dengan tujuan untuk mengambil keputusan untuk menjual atau membeli saham suatu perusahaan. Menurut Sawidji (2000), faktor utama yang menyebabkan harga saham adalah presepsi yang berbeda dari masing-masing investor sesuai dengan informasi yang didapat.

Brigham \& Houston (2001) ada tiga model penilaian saham biasa yaitu zero growth stock, constant growth stock, dan supernormal growth stock, yang masing-masing dirumuskan :

a. Zero Growth Stock

$$
P_{0}=\frac{D_{0}}{K_{S}}
$$

b. Constant Growth Stock

$$
\mathrm{P}_{0}=\frac{D_{\cup(1+g)}}{K_{S-g n}}
$$

c. Supernormal Growth Stock

$$
\mathrm{P}_{0=} \frac{D_{\mathrm{U}(1+g)}}{K_{S-g n}}+\frac{1}{\left(1+K_{S}\right)^{N}} \times \frac{D_{n+\mathbf{1}}}{k_{S}-g n}
$$

Keterangan : $\mathrm{D}_{0}=$ deviden yang dibagikan saat ini; $\mathrm{Ks}=$ tingkat pengembalian yang diharapkan; $\mathrm{Gn}=$ pertumbuhan normal; $\mathrm{Gs}=$ pertumbuhan super normal; $\mathrm{P}_{0}=$ harga saham sekarang; $D_{n}=$ dividen pada tahun ke-n

Dari rumus-rumus perhitungan penilaian harga saham biasa tersebut, dapat disimpulkan bahwa harga pasar saham $\left(\mathrm{P}_{0}\right)$ dapat dipengaruhi oleh tiga faktor, yaitu dividen $\left(\mathrm{D}_{0}\right)$, tingkat pengembalian yang diharapkan $\left(\mathrm{K}_{\mathrm{s}}\right)$, dan pertumbuhan $(\mathrm{g})$. 
Permasalahan dalam penelitian ini adalah: (1) Apakah nilai tukar RP/USD,suku bunga SBI,harga emas dunia, dan Indeks Dow Jones memiliki pengaruh secara bersama-sama terhadap indeks harga LQ45?; (2) Apakah nilai tukar RP/USD memiliki pengaruh secara parsial terhadap indeks harga LQ45?; (3) Apakah suku bunga SBI memiliki pengaruh secara parsialterhadap indeks harga LQ45?; (4) Apakah harga emas dunia memiliki pengaruh secara parsial terhadap indeks harga LQ45?; (5) Apakah Indeks Dow Jones memiliki pengaruh secara parsial terhadap indeks harga LQ45?; (6) Apakah Indeks LQ45 dalam jangka panjang mencapai keseimbangan akibat adanya perubahan variabel nilai tukar RP/USD,suku bunga SBI,harga emas dunia, dan Indeks Dow Jones?

\section{METODE}

Populasi, Sampel, dan Data. Populasi penelitian ini adalah Indeks Harga Saham Gabungan. Penelitian ini menggunakan sampel harga indeks LQ45 selama Januari 2009September 2014 dengan waktu pengamatan selama 69 bulan.

Data harga indeks LQ45 diperoleh dari publikasi www.idx.co.id, kurs / nilai tukar Rupiah terhadap US Dollar dan tingkat suku bunga SBI diperoleh dari publikasi www.bi.go.id, harga emas dunia diperoleh dari publikasi www.lbma.org.uk, sedangkan Indeks Dow Jones diperoleh dari publikasi www.yahoofinance.com.

Definisi Operasional dan Pengukuran, (1) LQ45 Index(LQ45) merupakan indeks yang terdiri dari 45 perusahaan yang memiliki likiuditas tinggi dan kapitalisasi pasar di BEI yang diukur berdasarkan closing priceperiode bulan Januari 2009 - September 2014; (2) Kurs/nilai tukar Rupiah terhadap US Dollar (KURS) merupakan harga satu unit mata uang Dollar AS dalam Rupiah dengan menggunakan kurs tengah periode bulan Januari 2009 September 2014; (3) Suku bunga SBI(SBI) merupakan suku bunga riil yang dikeluarkan oleh Bank Indonesia selama bulan Januari 2009 - September 2014; (4) Harga emas dunia (GOLD)merupakan harga yang terbentuk dari akumulasi penawaran dan permintaan di pasar emas Londonselama periode bulan Januari 2009 - September 2014; (5) Indeks Dow Jones Industrial Average (DJIA) merupakan indeks tertua di Amerika yang digunakan sebagai tolok ukur kinerja bursa saham yang paling banyak dipakai di duniayang diukur berdasarkan closing price periode bulan Januari 2009 - September 2014.

\section{Pengujian Model. Uji Stasioneritas Data (Unit Root Test) - Augmented Dickey-Fuller (ADF) Test}

Menurut Ajijah (2011), ADF Test digunakan ketika $u_{t}$ saling berkorelasi. Tes ini dilakukan dengan menambah (augmenting) nilai lag pada variabel dependen. Secara spesifik, tes ADF mengikuti persamaan di bawah ini.

$\Delta Y_{t}=\beta_{1}+\beta_{2} t+\delta Y_{t-1}+\sum_{i=1}^{I n} \alpha_{i} \Delta Y_{t-1}+\varepsilon_{t}$

Dimana $\varepsilon_{t}$ adalah white noise error term murni dan $\Delta Y_{t-1}=\left(Y_{t-1}-Y_{t-1}\right)$, $\Delta Y_{t-1}=\left(Y_{t-2}-Y_{t-3}\right)$, dan seterusnya. Dalam tes ADF, menguji apakah $\delta=\mathbf{0}$ atau tidak, dan tes ADF masih mengikuti distribusi asimtotik.

Selanjutnya, untuk mengetahui ada tidaknya unit root : 
$\mathrm{H}_{0}: \delta=0$ (terdapat unit root, artinya data time series tidak stasioner)

$\mathrm{H}_{1}: \neq 0$ (tidak terdapat unit root, artinya data time series stasioner)

Uji Derajat Integrasi/Differencing. Apabila terdapat data yang tidak bersifat stasioner pada uji stasioneritas, maka harus dilakukan uji differencing pada data tersebut untuk mengubah data tersebut menjadi data yang stasioner.

Enders (1995) menuliskan cara yang dapat dilakukan untuk mengubah data yang tidak stasioner menjadi data yang stasioner yaitu: melakukan differencing pada level 1 (first difference). Apabila data sudah stasioner maka dapat dilanjutkan ketahap berikutnya.Namun, apabila data belum bersifat stasioner perlu dilakukan differencing level 2 (second difference).

UjiKointegrasi. Kointegrasi adalah suatu keadaan dimana ditemukan dua variabel yang tidak stasioner, tetapi kombinasi linear antara dua variable tersebut merupakan data time series yang stasioner. (NachrowidanUsman, 2006).Pengujian kointegrasi antara variabel bertujuan menunjukkan adanya hubungan atau keseimbangan jangka panjang pada variabel bebas terhadap variabel terikat. Struktur hipotesis pengujian dilakukan pada model sebagai berikut:

$$
\Delta \hat{\mathrm{U}} \mathrm{t}=\gamma \hat{\mathrm{U}}_{\mathrm{t}-1}
$$

Keterangan: $\Delta=$ turunan pertama (first difference); $\hat{U} \mathrm{t}=$ nilai deviasi dari keseimbangan jangka panjang pada periode $\mathrm{t}$; $\hat{\mathrm{U}}_{\mathrm{t}-1}=$ nilai deviasi dari keseimbangan jangka panjang pada periode ${ }_{\mathrm{t}-1}$; Dimana struktur hipotesis sebagai berikut :

$\mathrm{H}_{0}: \gamma=0 \quad \hat{\mathrm{Ut}} \sim \mathrm{I}(1)$ (residual tidak stasioner, tidak ada kointegrasi)

$\mathrm{H}_{1}: \gamma<0 \quad \hat{\mathrm{Ut}} \sim I(0)$ (residual stasioner, ada kointegrasi)

Error Correction Model (ECM). Winarno (2011) ECM merupakan model yang digunakan untuk mengoreksi persamaan regresi di antara variabel - variabel yang secara individual tidak stasioner agar kembali kenilai equilibriumnya di jangka panjang, dengan syarat utamaberupa keberadaan hubungan kointegrasi di antara variabel - variable penyusunnya.Struktur hipotesis pengujian dilakukan pada model sebagai berikut:

$$
\Delta Y=b_{0}+b_{1} \Delta X_{t}+b_{2} E C+e_{t}
$$

Keterangan: $b_{0}=$ konstanta; $b_{1}=$ koefisien variabel bebas; $\mathrm{EC}=$ Error Correction;

Dimanastrukturhipotesissebagai berikut:

$\mathrm{H}_{0}:$ Prob $\varsigma 0,05$ (terjadi keseimbangan dalam jangka panjang)

$\mathrm{H}_{\mathrm{a}}:$ Prob $>0,05$ (tidak terjadi keseimbangan dalam jangka panjang)

Uji asumsi klasik. Multikolinearitas. Multikolinearitas berarti adanya hubungan linear yang sempurna atau pasti, di antara beberapa atau semua variabel yang menjelaskan dari model regresi (Ajijah (2011). Ada atau tidaknya multikolinearitas dapat diketahui atau dilihat dari koefisien korelasi masing - masing variabel bebas. Jika koefisien korelasi di antara masing - masing variabel bebas lebih besar dari 0,8 maka terjadi multikolinearitas. 
Otokorelasi. Autokorelasi dalam persamaan regresi menunjukkan adanya korelasi antara residual serangkaian observasi yang diurutkan menurut waktu atau ruang (Ajijah (2011). Hal-hal yang dapat dilakukan ntuk mendektesi adanya autokorelasi sebagai berikut:

a) Memperhatikan nilai $t$-statistik, $R^{2}$, uji $F$, dan Durbin Watson (DW) statistik.

b) Melakukan uji LM (metode Bruesch Godfrey). Metode ini didasarkan pada nilai $F$ dan Obs*R-Squared, di mana jika nilai probabilitas dari Obs*R-Squared melebihi tingkat kepercayaan, maka $\mathrm{H}_{0}$ diterima. Artinya tidak ada masalah autokorelasi.

Heteroskedastisitas. Heteroskedasitas merupakan keadaan dimana semua gangguan yang muncul dalam fungsi regresi populasi tidak memiliki varians yang sama (Ajijah (2011). Uji heteroskedastisitas dapat dilakukan dengan cara sebagai berikut: (a) Melihat pola residual dari hasil estimasi regresi. Jika residual bergerak konstan, maka tidak ada heteroskedastisitas. Akan tetapi, jika residual membentuk suatu pola tertentu, maka hal tersebut mengindikasikan adanya heteroskedastisitas. (b) Untuk membuktikan dugaan pada uji heteroskedastisitas pertama, maka dilakukan uji White Heteroscedasticity yang tersedia dalam program Eviews. Hasil yang diperhatikan dari uji ini adalah nilai $F$ dan $O b s * R$-Squared. Jika nilai $O b s * R$-Squared lebih kecil dari $X^{2}$ tabel, maka tidak terjadi heteroskedastisitas. Akan tetapi, jika nilai $O b s * R$-Squared lebih besar dari $X^{2}$ tabel, maka terjadi heteroskedastisitas.

Normalitas. Uji normalitas hanya digunakan jika jumlah observasi adalah kurang dari 30, untuk mengetahui apakah error term mendekati distribusi normal (Ajijah (2011). Jika jumlah observasi lebih dari 30, maka tidak perlu dilakukan uji normalitas karena distribusi sampling error term telah meendekati normal. Uji normalitas dapat ditempuh dengan Uji Jarque-Berra (JB test).

Uji Pengaruh Variabel Bebas secara bersama-sama terhadap Variabel Terikat (Uji F). Uji statistik F pada dasarnya menunjukan apakah semua variabel independen atau bebas yang dimasukkan dalam model mempunyai pengaruh secara bersama-sama terhadap variabel dependen atau terikat.

Uji Parsial (Uji Statistik t). Uji statistik t pada dasarnya menunjukan seberapa jauh pengaruh satu variabel penjelas/independen secara individual dalam menerangkan variasi variabel dependen dan dilakukan untuk menguji koefisien regresi secara parsial, yaitu untuk menguji apakah terdapat pengaruh yang signifikan dari suatu variabel independen terhadap variabel dependen.

Uji Koefisien Determinasi. Koefisien determinasi (Goodness of Fit), yang di notasikan dengan $\mathrm{R}^{2}$, merupakan suatu ukuran yang penting dalam regresi, karena dapat menginformasikan baik atau tidaknya model regresi yang terestimasi. Atau dengan kata lain, angka tersebut dapat mengukur seberapa dekatkah garis regresi yang tersetimasi dengan data sesungguhnya. (Nachrowi \& Usman, 2006).

Pembahasan. Statistik Deskriptif Data Penelitian. Pengamatan terhadap data yang digunakan dalam penelitian ditunjukkan dalam tabel 1. Nilai skewness lebih besar dari 0 mengindikasikan data lebih menumpuk pada nilai rendah, kecuali variabel LQ45, harga emas dunia, dan Indeks Dow Jones.Nilai Kurtosis yang lebih besar dari 3 mengindikasikan 
adanya gejala heteroskedastisitas, kecuali variabel kurs, suku bunga SBI, harga emas dunia dan Indeks Dow Jones.

Tabel 1. Statistik Deskriptif Variabel Penelitian

\begin{tabular}{lccccc}
\hline & DJIA & GOLD & KURS & LQ45 & SBI \\
\hline Mean & 9.414299 & 7.195394 & 9.194389 & 6.444149 & -2.718928 \\
Median & 9.426608 & 7.195562 & 9.159030 & 6.523020 & -2.733368 \\
Maximum & 9.746743 & 7.484930 & 9.407522 & 6.772027 & -2.436116 \\
Minimum & 8.862615 & 6.793746 & 9.051579 & 5.517485 & -2.855970 \\
Std. Dev. & 0.216475 & 0.195137 & 0.107499 & 0.278592 & 0.104441 \\
Skewness & -0.398278 & -0.416824 & 0.690699 & -1.554070 & 0.303990 \\
Kurtosis & 2.568008 & 2.252878 & 2.119069 & 5.288879 & 2.421424 \\
Jarque-Bera & 2.360714 & 3.602831 & 7.717364 & 42.83607 & 2.025124 \\
Probability & 0.307169 & 0.165065 & 0.021096 & 0.000000 & 0.363287 \\
Sum & 649.5866 & 496.4822 & 634.4129 & 444.6463 & -187.6061 \\
Sum Sq. Dev. & 3.186563 & 2.589325 & 0.785806 & 5.277711 & 0.741742 \\
Observations & 69 & 69 & 69 & 69 & 69 \\
\hline
\end{tabular}

Pengujian Akar Unit (Unit Root Test). Hasil pengujian ada atau tidaknya Unit Root untuk setiap variabel yang digunakan dalam penelitian ini diperlihatkan pada tabel 2 berikut

Tabel 2. Hasil Uji Stasioner Data Tingkat Level

\begin{tabular}{ccc}
\hline \multirow{2}{*}{ Variabel } & \multicolumn{2}{c}{ ADF (Augmented Dickey-Fuller Test) } \\
\cline { 2 - 3 } & Nilai Probabilitas & Kesimpulan \\
\hline KURS & 0.5253 & Tidak Stasioner \\
SUKU BUNGA SBI & 0.2607 & Tidak Stasioner \\
HARGA EMAS DUNIA & 0.2525 & Tidak Stasioner \\
DOW JONES & 0.6229 & Tidak Stasioner \\
LQ45 & 0.0052 & Stasioner \\
\hline
\end{tabular}

Tabel 2 menunjukkan bahwa kurs, suku bunga SBI, harga emas dunia, dan Indeks Dow Jones belum stasioner. Ajija (2011) menyatakan, apabila salah satu variabel stasioner pada tingkat first difference, maka semua variabel harus stasioner pada tingkat first difference juga. Karena pada level hanya variabel LQ45 yang stasioner, sehingga dilakukan pengujian pada first difference dengan hasil seperti ditunjukkan pada Tabel 3 berkut:

Tabel 3. Hasil Estimasi Akar Unit Pada Tingkat First Differencing

\begin{tabular}{ccc}
\hline \multirow{2}{*}{ Variabel } & \multicolumn{2}{c}{ ADF (Augmented Dickey-Fuller Test) } \\
\cline { 2 - 3 } & Nilai Probabilitas & Kesimpulan \\
\hline KURS & 0.0000 & Stasioner \\
SUKU BUNGA SBI & 0.0030 & Stasioner \\
HARGA EMAS DUNIA & 0.0000 & Stasioner \\
DOW JONES & 0.0000 & Stasioner \\
LQ45 & 0.0000 & Stasioner \\
\hline
\end{tabular}


Pada tabel 3 ditunjukkan semua variabel sudah stasioner pada tingkat first difference, yang dibuktikan dengan nilai p-value Augmented Dickey-Fuller Test (ADF Test) yang lebih kecil dari $5 \%$.

Pengujian Kointegrasi. Pengujian ini dilakukan untuk mendeteksi apakah dalam jangka panjang terdapat keseimbangan dalam perubahan harga saham akibat adanya perubahan dari variabel kurs, suku bunga SBI, harga emas dunia dan indek saham Dow Jones. berikut;

Berdasarkan hasil pengujian kointegrasi dengan menggunakan hipotesisi seperti

$\mathrm{H}_{0}: \gamma=0 \quad \hat{\mathrm{U}} \sim I(1)$ (residual tidak stasioner, tidak ada kointegrasi)

$\mathrm{H}_{\mathrm{a}}: \gamma<0 \quad \hat{\mathrm{Ut}} \sim \mathrm{I}(0)$ (residual stasioner, ada kointegrasi) diperoleh hasilnya seperti ditunjukkan oleh tabel 4

Tabel 4. Hasil Uji Kointegrasi

Dependent Variable: DRESID

Method: Least Squares

Date: 11/17/14 Time: 10:40

Sample (adjusted): 2009M03 2014M09

Included observations: 67 after adjustments

\begin{tabular}{lllll}
\hline \hline Variable & Coefficient & Std. Error & t-Statistic & Prob. \\
\hline \hline RESID02 & 1.123361 & 0.122454 & 9.173750 & 0.0000 \\
C & 0.000540 & 0.004927 & 0.109518 & 0.9131 \\
\hline \hline
\end{tabular}

Dari hasil yang diperoleh, nilai probabilitas $=0,000$. Berarti $\mathrm{H}_{0}$ ditolak. Artinya, adanya kointegrasi pada variabel bebas (kurs, suku bunga SBI, harga emas dunia, Indeks Dow Jones) terhadap variabel terikat (Indeks LQ45).

Pengujian ECM. Untuk melihat apakah dalam jangka panjang terjadi konvergensi terhadap indek harga saham LQ45 akibat adanya gejolak pada variabel kurs, suku bunga SBI, harga emas dunia dan indek harga saham Dow Jones digunakan pengujian menggunakan model Error Correction Model (ECM) dengan hipotesis seperti berikut;

$\mathrm{H}_{0}:$ Prob $\boldsymbol{\varsigma} 0,05$ (terjadi keseimbangan dalam jangka panjang)

$\mathrm{H}_{\mathrm{a}}$ :Prob> 0,05 (tidak terjadi keseimbangan dalam jangka panjang)

Tabel 5. Hasil Uji ECM

Dependent Variable: D(LQ45)

Method: Least Squares

Date: 11/17/14 Time: 10:44

Sample (adjusted): 2009M03 2014M09

Included observations: 67 after adjustments

\begin{tabular}{lllll}
\hline \hline Variable & Coefficient & Std. Error & t-Statistic & Prob. \\
\hline \hline D(KURS) & -0.888360 & 0.277260 & -3.204067 & 0.0022 \\
D(SBI) & -0.348372 & 0.240907 & -1.446084 & 0.1533 \\
D(GOLD) & 0.053504 & 0.100815 & 0.530715 & 0.5975 \\
D(DJIA) & 0.729977 & 0.146650 & 4.977668 & 0.0000
\end{tabular}




\begin{tabular}{lllll} 
RESID01(-1) & -0.143135 & 0.134787 & -1.061933 & 0.2925 \\
C & 0.008427 & 0.005402 & 1.559994 & 0.1239 \\
\hline \hline R-squared & 0.490398 & Mean dependent var & 0.018725 \\
Adjusted R-squared & 0.448628 & S.D. dependent var & 0.055766 \\
S.E. of regression & 0.041409 & Akaike info criterion & -3.445357 \\
Sum squared resid & 0.104596 & Schwarz criterion & -3.247921 \\
Log likelihood & 121.4194 & Hannan-Quinn criter. & -3.367231 \\
F-statistic & 11.74026 & Durbin-Watson stat & 2.004777 \\
Prob(F-statistic) & 0.000000 & &
\end{tabular}

Dari hasil yang diperoleh, nilai probabilitas resid01(-1)= 0,2925. Berarti $\mathrm{H}_{0}$ ditolak. Artinya menunjukkan bahwa indeks LQ45 dalam jangka panjang tidak mencapai keseimbangan akibat adanya perubahan variabel makroekonomi (kurs, suku bunga SBI, harga emas dunia) dan indeks saham global (Indeks Dow Jones). Tidak mencapai keseimbangan ini berarti bahwa pada saat terjadi gejolak pada faktor-faktor yang mempengaruhi indeks harga LQ45 (kurs, suku bunga SBI, harga emas dunia dan indeks Dow Jones), nilai indeks LQ45 tidak kembali ke titik semula.

Pengujian Asumsi klasik. Multikolinearitas. Hasil analisis multikolineritas dapat dilihat pada tabel 6 berikut. Perumusan hipotesis dari multikolinearitas ini adalah :

$\mathrm{H}_{0}=$ Koefisien korelasi di antara masing - masing variabel di atas 0,8 maka terjadi multikolinearitas.

$\mathrm{H}_{\mathrm{a}}=$ Koefisien korelasi di antara masing - masing variabel di bawah 0,8 maka tidak terjadi multikolinearitas.

Tabel 6. UjiMultikolinearitas

\begin{tabular}{lcrrr}
\hline & DJIA & GOLD & KURS & \multicolumn{1}{c}{ SBI } \\
\hline DJIA & 1.000000 & 0.557192 & 0.294314 & -0.092236 \\
GOLD & 0.557192 & 1.000000 & -0.434294 & -0.616721 \\
KURS & 0.294314 & -0.434294 & 1.000000 & 0.670243 \\
SBI & -0.092236 & -0.616721 & 0.670243 & 1.000000 \\
\hline
\end{tabular}

Pada hasil output diatas dapat dilihat bahwa koefisien korelasi di antar variabel di bawah 0,8. jadi dapat disimpulkan bahwa tidak ada masalah multikolinieritas antar variabel independen dalam model regresi.

Autokorelasi. Hasil analisis otokorelasi dapat dilihat pada Tabel 7. Perumusan hipotesis dari otokorelasi ini adalah :

$\mathrm{H}_{0}=$ Probabilitas di atas $5 \%$ maka tidak terdapat otokorelasi.

$\mathrm{H}_{\mathrm{a}}=$ Probabilitas di bawah 5\% maka terdapat otokorelasi.

Tabel 7. UjiAutokorelasi

Breusch-Godfrey Serial Correlation LM Test:

\begin{tabular}{llll}
\hline \hline F-statistic & 1.626955 & Prob. F(2,61) & 0.2049 \\
Obs*R-squared & 3.443618 & Prob. Chi-Square(2) & 0.1787 \\
\hline \hline
\end{tabular}


Hasil pengujian autokorelasi diperoleh bahwa hipotesis null tidak ditolak yang dapat dilihat dari prob.Chi-Square sebesar 0.1787 dan angka tersebut lebih besar daripada 0.05 sehingga dapat disimpulkan bahwa tidak terdapat otokorelasi pada data residual.

Heteroskedastisitas. Pada pengujian heteroskedastisitas ini akan dilakukan dengan uji White.

Hipotesis dari pengujian ini adalah:

$\mathrm{H}_{0}=$ Probabilitas di atas 5\% maka tidak terdapat heteroskedastisitas.

$\mathrm{H}_{\mathrm{a}}=$ Probabilitas di bawah 5\% maka terdapat heteroskedastisitas.

Hasil analisis uji heteroskedastisitas dapat dilihat pada Tabel 8.

Tabel 8.UjiHeteroskedastisitas

Heteroskedasticity Test: White

\begin{tabular}{llll}
\hline \hline & & & \\
F-statistic & 0.232572 & Prob. F(4,63) & 0.9190 \\
Obs*R-squared & 0.989508 & Prob. Chi-Square(4) & 0.9114 \\
Scaled explained SS & 0.897016 & Prob. Chi-Square(4) & 0.9250 \\
\hline \hline
\end{tabular}

Dari hasil pengolahan data diatas, dapat dilihat probabilitas dari uji heteroskedastisitas adalah sebesar 0.9114. Hal ini menunjukan bahwa $\mathrm{H}_{0}$ tidak ditolak, sehingga dapat disimpulkan bahwa tidak terjadi heteroskedastisitas dan persamaan tersebut baik untuk digunakan.

Normalitas. Uji normalitas dapat dilakukan dengan Uji Jarque-Berra (JB test).

Hipotesis dari pengujian ini adalah:

$\mathrm{H}_{0}=$ Probabilitas di atas 5\% maka error term terdistribusi normal.

$\mathrm{H}_{\mathrm{a}}=$ Probabilitas di bawah 5\% maka error term tidak terdistribusi normal.

Hasil analisis uji normalitas dapat dilihat pada gambar 1 berikut.

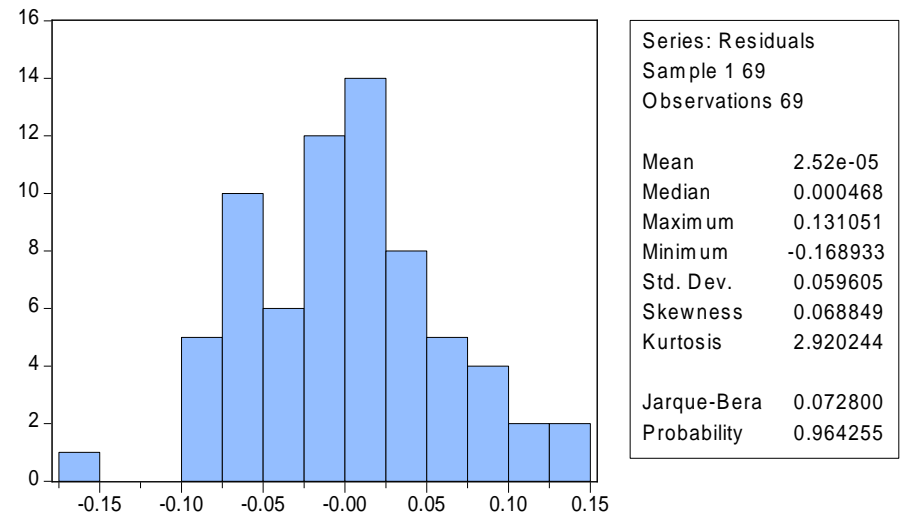

\section{Gambar 1. Histogram Pengujian Normalitas}


Dari hasil pengolahan data diatas, dapat dilihat probabilitas dari uji normalitas adalah sebesar 0.964255. Hal ini menunjukan bahwa probabilitas berada di atas 5\% sehingga dapat disimpulkan bahwa error term terdistribusi normal dan persamaan tersebut baik untuk digunakan.

\section{Pengujian Hipotesis}

\section{Uji F (secara bersama-sama)}

Dari hasil data analisis regresi berganda pada tabel 5, dapatdilihat bahwa Prob. FStatsebesar $0,000000<$ dari 0,05 , hal ini menunjukkan bahwa terdapat pengaruh secara bersama - sama antara variabel kurs, sukubunga SBI, harga emas dunia, dan Indeks Dow Jones terhadapIndeksHarga LQ45.

\section{Uji t (secara parsial)}

Tujuan dari uji ini adalah untukmengujiapakahterdapatpengaruh yang signifikandarisuatuvariabelindependenterhadapvariabeldependen. Hasil pengujian dipaparkan pada tabel 9 berikut ini.

\section{Tabel 9. HasilUji t(Parsial)}

\begin{tabular}{|l|c|r|}
\hline Variabel & Prob (t-statistic) & Coefficient \\
\hline KURS & $-0,888360$ & 0,0022 \\
\hline SUKU BUNGA SBI & $-0,348372$ & 0,1533 \\
\hline HARGA EMAS DUNIA & 0,053504 & 0,5975 \\
\hline INDEKS DOW JONES & 0,729977 & 0,0000 \\
\hline
\end{tabular}

Dari tabel 9, dapat disimpulkan bahwa pengujian secara parsial untuk kursRP/USD memiliki p-valuesebesar 0,0063, suku bunga SBI sebesar 0.1533, harga emas dunia sebesar 0.5975 dan Indeks Dow Jones sebesar 0,0000. Berarti, secara statistik variabel harga emas dunia dan suku bunga SBI tidak memiliki pengaruh terhadap perubahan indek harga saham.

Sedangkan pengujian secara bersama-sama pengaruh semua variabel bebas terhadap variabel terikat memiliki $p$-value sebesar 0,000000 yang artinya terdapat pengaruh variable independen (kurs RP/USD, suku bunga SBI, harga emas dunia,danIndeks Dow Jones) secara bersama-sama terhadapvariabledependen (Indeks LQ45), atau paling tidak ada satu variabel independen yang memiliki pengaruh yang berarti terhadap variabel dependen secara statistik.

Berdasarkan hasil pengolahan data yang dilakukan, diketahui bahwa variabel kurs RP/USDmempunyai nilai koefisien sebesar -0.888360 dan probabilitas sebesar 0.0022 , dimana probabilitas tersebut lebih kecil dari $\alpha$ sebesar 5\%. Oleh karena itu variabel kurs RP/USDmempunyai pengaruh negatif dan signifikan terhadap harga saham. Hal ini konsisten terhadap penelitian yang dilakukan oleh Lestari (2005) dan Astuti (2013) yang menemukan bahwa kurs RP/USD berpengaruh negatif dan signifikan. Nilai tukar RP/USD memiliki pengaruh negatif signifikan terhadap harga saham ini menunjukkan ketika nilai tukar Rupiah terapresiasi maka Indeks Harga LQ45 akan melemah. Bagi investor, pelemahan nilai kurs rupiah akan menyebabkan menguatnya harga saham. Hal ini dikarenakan pada saat harga kurs Rupiah melemah, pasar saham akan menjadi tempat yang menarik bagi investor untuk berinvestasi. Para investor yang melakukan pembelian saham di BEI akan menyebabkan meningkatnya harga saham. 
Suku bunga SBImempunyai nilai koefisien sebesar -0.348372 dan probabilitas sebesar 0.1533 , dimana probabilitas tersebut lebih besar dari $\alpha$ sebesar 5\%. Oleh karena itu variabel suku bunga SBI secara statistik tidak mempunyai pengaruh terhadap harga saham. Hasil ini konsisten terhadap penelitian yang dilakukan oleh Astuti (2013) yang menemukan bahwa suku bunga SBI berpengaruh negatif dan signifikan terhadap indeks harga saham.Suku bunga SBI memiliki pengaruh negatif terhadap harga saham ini menunjukkan bahwa di dalam pasar modal yang masih berkembang seperti BEI cara pola investasi masih ada kecenderungan berinvestasi di pasar uang sehingga perubahan suku bunga akan berdampak langsung terhadap preferensi investor karena motivasi investasi di negara berkembang masih bersifat jangka pendek.

Selanjutnya harga emas duniamempunyai nilai koefisien sebesar 0.053504 dan probabilitas sebesar 0.5975 , dimana probabilitas tersebut lebih besar dari $\alpha$ sebesar 5\%. Oleh karena itu variabel harga emas duniatidak mempunyai pengaruh yang signifikan terhadap harga saham. Hasil penelitian ini konsisten terhadap penelitian yang dilakukan oleh Smith (2001) yang menemukan bahwa harga emas dunia tidak berpengaruh signifikan terhadap indeks harga saham.Harga emas dunia tidak memiliki pengaruh yang signifikan terhadap harga saham ini dikarenakan tujuan masyarakat membeli emas bukan tujuan berinvestasi melainkan digunakan untuk tujuan konsumtif yakni sebagai perhiasan.

Disamping faktor suku bunga SBI, nilai tukar dan harga emas dunia, penelitian ini menemukan bahwa Indeks Dow Jonesmempunyai nilai koefisien sebesar 0.729977 dan probabilitas sebesar 0.0000 , dimana probabilitas tersebut lebih kecil dari $\alpha$ sebesar $5 \%$. Oleh karena itu variabel Indeks Dow Jonesmempunyai pengaruh positif dan signifikan terhadap harga saham. Hasil ini konsisten denga penelitian yang dilakukan oleh Venska et al. (2014) yang menemukan bahwa Indeks Dow Jones Industrial Average berpengaruh positif dan signifikan terhadap indeks harga saham.Hal itu dapat terjadi karena pengaruh Amerika Serikat di dalam perekonomian dunia cukup signifikan. Pasar saham di Amerika Serikat memiliki pengaruh yang besar di pasar saham global, termasuk Indonesia. Dengan menggunakan teori signal (signalling theory), perubahan informasi dalam bursa saham akan dikirim ke pasar di negara lain, dimana bursa efek yang lebih besar (Amerika Serikat) akan mempengaruhi bursa saham yang lebih kecil (Mansur, 2005) dalam Venska et al. (2014), sehingga investor akan mendapatkan informasi itu dan investor dapat menggunakan informasi tersebut sebagai pertimbangan dalam menginvestasikan dananya.

\section{Uji Goodness of Fit $\mathbf{R}^{2}$}

Berdasarkan Adj. R-Squared tabel 5, besarnya pengaruh dari variabel independen yaitu kurs, suku bunga SBI, harga emas dunia, dan Indeks Dow Jones terhadap Indeks Harga LQ45 di Bursa Efek Indonesia adalah sebesar 0.490398 atau 49,0398\%. Sedangkan sisanya 0,509602 atau 50,9602\% dipengaruhi oleh variabel lain seperti tingkat inflasi, pertumbuhan GDP, faktor sosial, ekonomi, politik dan lainnya.

\section{Kesimpulan}

a) Kurs RP/USD, suku bunga SBI, harga emas dunia, dan Indeks Dow Jones secara bersama - sama memiliki pengaruh yang signifikan terhadap Indeks Harga LQ45

b) Kurs RP/USD memiliki pengaruh negatif dan signifikan terhadap Indeks Harga LQ45

c) Suku bunga SBI memiliki pengaruh negatif dan tidak signifikan terhadap Indeks Harga LQ45 
d) Harga emas dunia tidak memiliki pengaruh yang signifikan terhadap Indeks Harga LQ45

e) Indeks Dow Jones memiliki pengaruh positif dan signifikan terhadap Indeks Harga LQ45

f) Indeks LQ45 dalam jangka panjang tidak mencapai keseimbangan akibat adanya perubahan variabel kurs, suku bunga SBI, harga emas dunia, dan Indeks Dow Jones.

\section{Saran}

Berdasarkan hasil penelitian ini, maka penulis dapat menyampaikan beberapa saran, yaitu:

Bagi para investor untuk lebih berhati - hati dan harus berpikir rasional dalam mengambil keputusan untuk berinvestasi, khususnya di pasar modal. Investor seharusnya mengikuti perkembangan informasi mengenai tingkat inflasi, suku bunga SBI, kurs RP/USD yang dikeluarkan Bank Indonesia, sehingga informasi tersebut dapat dijadikan panduan dalam memprediksi harga saham dan menginvestasikan dana perusahaan.

Untuk penelitian selanjutnya yang ingin meneliti tentang pengaruh beberapa indeks saham dan indikator ekonomi global terhadap kondisi Pasar Modal Indonesia dapat mempertimbangkan variabel indeks negara-negara Asia Pasific lainnya seperti: indeks Hangseng (Hongkong), indeks Kospi (Korea Selatan), dan variabel makroekonomi Indonesia seperti: inflasi, tingkat PDB , cadangan devisa. Mengingat pergerakan LQ45 cenderung dipengaruhi oleh saham-saham berkapitalisasi besar dan variabel makroekonomi, maka pada penelitian selanjutnya dapat menggunakan indeks sektoral ataupun indeks lainnya serta variabel makroekonomi lainnya sebagai variabel independen.

Sementara untuk Pemerintahharus lebih cermat dalam membuat kebijakan-kebijakan yang berhubungan dengan makroekonomi karena kebijakan-kebijakan itu yang mempengaruhi iklim investasi sehingga mampu menarik minat investor baik domestik maupun asing di Bursa Efek Indonesia. Disamping itu, Pemerintah sebaiknya berusaha menjaga stabilitas perekonomian untuk menghindari fluktuasi faktor-faktor makroekonomi seperti kurs RP/USD, suku bunga SBI, dan inflasi yang dapat mempengaruhi harga saham yang juga berimbas pada peningkatan di pasar modal dengan mengeluarkan kebijakan yang dapat menjaga stabilitas perekonomian.

\section{Daftar Pustaka}

Ajija, S. R. (2011). Cara Cerdas Menguasai Eviews. Salemba Empat.

Amin, M. Z. (2012). Pengaruh Tingkat Inflasi, Suku Bunga SBI, Nilai Kurs Dollar (USD/IDR), Dan Indeks Dow Jones (DJIA) Terhadap Pergerakan Indeks Harga Saham Gabungan Di Bursa Efek Indonesia (BEI) (PERIODE 2008-2011).

Aritonang R., Lerbin R. (2007). Riset Pemasaran: Teori \& Praktik. Bogor: Ghalia Indonesia.

Brigham, E.F., dan J. Houston. 2001. Manajemen Keuangan. Penerjemah Hermawan Wibowo. Edisi Kedelapan. Edisi Indonesia. Buku II. Jakarta: Erlangga.

Darmadji T., Fakhruddin H.M. (2006). Pasar Modal Di Indonesia, Edisi Kedua. Jakarta: Penerbit Salemba Empat.

Efni, Y. (2009). Pengaruh Suku Bunga Deposito, SBI, Kurs dan Inflasi Terhadap Harga Saham Perusahaan Real Estate dan Property di BEI. Jurnal Manajemen Fakultas Ekonomi Universitas Riau Kampus Bina Widya Km.12,5. 
Enders, W. (1995). Applied Econometric Time Series. New York: John Wiley and Sons.

Gitman, Lawrence. (2013). Principles of Managerial Finance. $13^{\text {th }}$ Edition. Boston: Pearson

Ismanthono, Henricus W. (2003). Kamus istilah ekonomi populer. Jakarta: Kompas.

Jones, Charles P. (2008). Investment :analysis and management (An Indonesian Adaption). New York: John Wiley\& Sons, Inc.

Keown et.al. (2002). Basic financial management. $8^{\text {th }}$ Edition. New Jersey: Prentice-Hall, Inc.

Kewal, S. S. (2012). Pengaruh Inflasi, Suku Bunga, Kurs, dan Pertumbuhan PDB Terhadap Indeks Harga Saham Gabungan. Jurnal Economia, Vol.8, No.1:53-64.

Lawrence, S.S. (2013). Pengaruh Variabel Makro Ekonomi dan Harga Komoditas Terhadap Indeks Harga Saham Gabungan Di Indonesia. Finesta, Vol.1 No.2, 18-23.

Lestari, M. (2005) . Pengaruh Variabel Makro terhadap Return Saham di Bursa Efek Jakarta: Pendekatan Beberapa model. SNAVIII Solo, 15-16 September 2005.

Nachrowi D. \& Hardinus Usman. (2006). Pendekatan Populer dan Praktis : Ekonometrika untuk Analisis Ekonomi dan Keuangan. Jakarta: Fakultas Ekonomi Universitas Indonesia.

Novitasari, Istriyansah. (2013). Pengaruh Inflasi, Harga Minyak Mentah Indonesia, Dan Suku Bunga (BI Rate) Terhadap Indeks Harga Saham Gabungan (IHSG) (Data per Bulan Periode 2006-2012).

Ria Astuti, A. E. (2013). Analisis Pengaruh Tingkat Suku Bunga (SBI), Nilai Tukar (Kurs) Rupiah, Inflasi, dan Indeks Bursa Internasional Terhadap IHSG (Studi Pada IHSG di BEI Periode 2008 - 2012). Dipenogoro Journal Of Social And Politic Of Science Tahun 2013, Hal 1 - 8.

Ross, Westerfield \& Jordan. (2003). Fundamental of Corporate Finance. $6^{\text {th }}$ Edition. New York : Mc. Graw Hill Inc.

Siamat, Dahlan. (2005). Manajemen Lembaga Keuangan Edisi Kelima.Jakarta: LPFE UI.

Smith, Graham. (2001). The Price Of Gold And Stock Price Indices For The United States.

Silim, Lusiana. (2013). Pengaruh Variabel Ekonomi Makro Terhadap Indeks Harga Saham Gabungan Pada Bursa Efek Indonesia Periode 2002-2011. Jurnal Ilmiah Mahasiswa Universitas Surabaya Vol.2 No.2.

Sukirno, Sadono. (2004). Makro Ekonomi Teori Pengantar. Edisi Ketiga. Jakarta: PT Raja Grafindo Persada.

Sunariyah. (1997). Pengantar Pengetahuan Pasar Modal.Edisi Pertama. Yogyakarta: UPP AMP YKPN.

Venska et.al. (2014). The Effect Of Global Stock Indexs (Dow Jones Industrial Average, Nikkei225, Hang Seng, And Strait Times) on Jakarta Composite Index At Indonesian Stock Exchange (Period of 2010-2012). Jurnal Administrasi Bisnis Vol.9 No. 2.

Widoatmodjo, S. (2000). Cara Sehat Investasi Pasar Modal. Jakarta: PT Elex Media Komputindo.

Winarno, Wing Wahyu. (2011). Analisis Ekonometrika dan Statistika dengan Eviews. Edisi 3. Yogyakarta: UPP STIM YKPN 